\title{
The effect of pelvic organ prolapse type on sexual function, muscle strength, and pelvic floor symptoms in women: $A$ retrospective study
}

\author{
Pelvik organ prolapsus tipinin kadınlarda seksüel fonksiyon, \\ kas kuvveti ve pelvik taban semptomları üzerine etkisinin \\ incelenmesi: Retrospektif araştırma
}

\author{
Nuriye Özengin, Hatice Çankaya, Elif Duygu, Muhammet Fatih Uysal, Yeşim Bakar \\ Abant İzzet Baysal University, School of Kemal Demir Physical Therapy and Rehabilitation, Bolu, Turkey
}

\begin{abstract}
Objective: This retrospective research was planned to investigate the effect of pelvic organ prolapse (POP) type on sexual function, muscle strength, and pelvic floor symptoms in symptomatic women.

Materials and Methods: Data on POP type and stages as assessed using the Pelvic Organ Prolapse-Quantification system of 721 women who presented to the women's health unit between 2009 and 2016 were collected retrospectively. POP types were recorded as asymptomatic, anterior, apical, and posterior compartment prolapses. Sexual function was assessed using the Pelvic Organ Prolapse/Urinary Incontinence Sexual Questionnaire short-form (PISQ-12), pelvic floor muscle strength was assessed through vaginal pressure measurement, and pelvic floor symptoms and quality of life were assessed using the Pelvic Floor Distress Inventory-20 (PFDI-20).

Results: Among 168 women who met the inclusion criteria, 96 had anterior compartment prolapses, 20 had apical compartment prolapses, 16 had posterior compartment prolapses, and 36 women were asymptomatic. There was no difference between the groups in their PISQ-12 total and subscales scores, PFDI-20 total and two subscale (colorectal/anal, urinary) scores, and muscle strength ( $\mathrm{p}>0.05$ ). In the Pelvic Organ Prolapse Distress Inventory-6, another subscale of PFDI-20, it was determined that there was a difference between asymptomatic women and those with anterior compartment prolapses ( $\mathrm{p}=0.044)$ and apical compartment prolapses $(\mathrm{p}=0.011)$.

Conclusion: This research found that POP type did not affect sexual function, muscle strength, and colorectal and urinary symptoms in our cohort. There were more prolapse symptoms and complaints in women with anterior and apical compartment prolapses.
\end{abstract}

Keywords: Pelvic organ prolapses, sexual function, muscle strength, pelvic floor symptoms

$\ddot{O} z$

Amaç: Bu retrospektif araştırma, pelvik organ prolapsus (POP) tipinin kadın seksüel fonksiyon, kas kuvveti ve pelvik taban semptomları üzerine etkisini incelemek amaciyla planlands.

Gereç ve Yöntemler: 2009-2016 tarihleri arasında kadın sağlı̆̆ı ünitesine yönlendirilen 721 kadının verileri retrospektif olarak değerlendirildi. Kadınların prolapsus tip ve evreleri Pelvik Organ Prolapsus-Sinıflaması testi ile değerlendirildikten sonra; asemptomatik, anterior, apikal ve posterior kompartman prolapsusu olarak kaydedildi. Seksüel fonksiyonları Pelvik Organ Prolapsus/Üriner İnkontinans Seksüel Değerlendirme kısa formu (PISQ-12) ile, pelvik taban kas kuvveti vajinal basınç ölçümü ile ve pelvik taban semptom, şikayet ve yaşam kalitesi Pelvik Taban Distres Envanteri-20 (PFDI-20) ile değerlendirildi. Bulgular: Dahil edilme kriterlerini karşılayan 168 kadının 96'sında anterior, 20'sinde apikal, 16'sında posterior kompartman prolapsusu ve 36 kadının da asemptomatik olduğu saptandı. Gruplar arasında; PISQ-12 toplam ve alt skala puanlarında, PFDI-20 toplam ve iki alt skala (kolorektal/anal, üriner) puanlarında ve kas kuvvetinde fark bulunmadı (p 0,05). PFDI-20'nin diğer alt skalası olan Pelvik Organ Prolapsus Distres Envanteri-6'da ise asemptomatik kadınlar ile anterior kompartman prolapsusu $(\mathrm{p}=0,044)$ ve apikal kompartman prolapsusu $(\mathrm{p}=0,011)$ olanlar arasında fark olduğu saptandl.

Sonuç: Bu araştırma ile POP tipinin seksüel fonksiyonu, kas kuvvetini, kolorektal ve üriner semptomları etkilemediği bulundu. Prolapsus semptom ve şikayetlerinin, anterior ve apikal kompartman prolapsusu olan kadınlarda daha fazla olduğu saptandı.

Anahtar Kelimeler: Pelvik organ prolapsusu, seksüel fonksiyon, kas kuvveti, pelvik taban semptomu

Address for Correspondence/Yazışma Adresi: Nuriye Özengin, PT, PhD

Abant İzzet Baysal University, School of Kemal Demir Physical Therapy and Rehabilitation, Bolu, Turkey

Phone: +903742541000 E-mail: ozenginnuriye@yahoo.com

Received/Geliș Tarihi: 15.01.2017 Accepted/Kabul Tarihi: 16.03.2017

${ }^{\oplus}$ Copyright 2017 by Turkish Society of Obstetrics and Gynecology

Turkish Journal of Obstetrics and Gynecology published by Galenos Publishing House 
PRECIS: Pelvic organ prolapse type did not affect sexual function, muscle strength, and colorectal and urinary symptoms.

\section{Introduction}

American College of Obstetricians and Gynecologists defined pelvic organ prolapses (POP) as prolapsing of the organs in the pelvis from inside and outside of the vaginal canal downward ${ }^{(1)}$. $\mathrm{POP}$ is described as anterior, posterior, and apical compartment prolapses according to their location in the vaginal canal ${ }^{(2)}$. POP symptoms may vary and may not necessarily be specific to any one compartment. Anterior compartment symptoms are urinary frequency, urgency, incontinence, intermittent flow, urinary difficulty, sense of incomplete discharge in the urinary bladder, and insufficient flow; posterior compartment symptoms are defecation difficulty, sense of incomplete discharge in bowels, constipation, and digital palpation need for discharge ${ }^{(3,4)}$. The only accepted symptom of POP seen in the three compartments is vaginal protrusion ${ }^{(4)}$. It was reported that POP prevalence ranged between 6-97\% and POP affected $50 \%$ of women who gave birth to various degrees and $20 \%$ of these were asymptomatic ${ }^{(4-7)}$.

POP is a serious public health problem that affects sexual function, quality of life, and psychological state; however, it is generally ignored by women. It was reported in that POP affected sexual function and life quality of women negatively ${ }^{(8-11)}$. However, a limited number of studies have contributed data regarding how women are affected by POP in relation to the prolapse compartment ${ }^{(12,13)}$. The objective of this research was to investigate the effect of prolapse compartments on sexual function, muscle strength, pelvic floor symptoms, and quality of life in symptomatic women.

\section{Materials and Methods}

\section{Participants}

This study was conducted retrospectively on 721 women who presented to Abant İzzet Baysal University, School of Kemal Demir Physical Therapy and Rehabilitation, Women's Health Unit, between November 2009 and January 2016. The inclusion criteria for the research were determined as being clinically diagnosed with stage 1 and over POP, being aged more than 18 years, sexually active, and speaking Turkish. Women who had symptoms of urinary and fecal incontinence without POP, any mental problems that hindered comprehension, neurologic or psychiatric illness, pregnancy, pelvic surgery history, incomplete assessment form, and the same stage POP in more than one compartment were excluded. Approval from the institutional review board and informed consent form all the participants were obtained (approval number: 2014/17).

The women included in the research were divided into 4 groups; women with stage 2 and above POP symptoms: anterior, apical and posterior, and asymptomatic women with stage 1 prolapse. The physical features of the women [age, body height, body weight, body mass index (BMI)] and their sociodemographic information (educational status, profession, menstrual status, obstetric anamnesis, and medical history) were recorded. Pelvic Organ Prolapse-Quantification (POP-Q) assessment, pelvic floor muscle strength, Pelvic Organ Prolapse/Urinary Incontinence Sexual Questionnaire short-form (PISQ-12), and Pelvic Floor Distress Inventory-20 (PFDI-20) data were taken from the women's files.

\section{Pelvic Organ Prolapse-Quantification}

POP-Q assessments of the women were made by a physiotherapist specialized in urogynecologic physiotherapy. POP-Q is a quantitative standardized measurement method used for determining POP localization and level. After the women were placed in the lithotomy position, anterior (Aa and $\mathrm{Ba}$ ), posterior (Ap and $\mathrm{Bp}$ ), apical (C and D), total vaginal length (TVL), genital hiatus, and perineal body $(\mathrm{PB})$ were measured using a rule and recorded in centimeters. In POP-Q assessment, with the exception for TVL, all values were recorded at maximal protrusion using the Valsalva maneuver. These measurement results were recorded in $3 \times 3$ table and POP staging was made. POP-Q stages range between 0 and 4 , and a high stage indicates more serious prolapses ${ }^{(14)}$. The women were classified as having anterior, apical, and posterior compartment POP, and asymptomatic POP based on these results.

\section{Pelvic floor muscle strength measurement}

Pelvic floor muscle strength was assessed through vaginal pressure measurement (Myomed 932 Enraf/Nonius ${ }^{\circledR}$ ). The women were positioned on their back with their hips and knees flexed. The contraction and resting periods of the device were adjusted to 10 seconds. After the placement of the vaginal probe into the vagina, the women were told to relax their pelvic floor muscles with the "relax" command, and to squeeze the placed vaginal probe and lift it inside without contracting their abdomen, hip and thigh muscles, and without holding their breath with the "contract" command. The measurement was repeated three times and pelvic floor muscle strength was recorded as hectopascal ${ }^{(15)}$.

\section{Pelvic Organ Prolapse/Urinary Incontinence Sexual Questionnaire-12}

Sexual function of women who were sexually active during the past six months were assessed using the Turkish version of PISQ-12. PISQ-12 is a valid and reliable condition-specific questionnaire that assesses behavioral/emotive, physical, and partner-related aspects of sexual function. The questionnaire provides information about sexual desire and activity frequency and orgasmic characteristics. PISQ-12 assesses the effect of POP on sexual function, women's perception, and how partners view pelvic floor disorders. In addition, it questions sexual function of partners. The questions are scored between 0 (never) and 
4 (always), and questions 5-12 are estimated inversely. The maximum score obtainable from each section is 16 . The total score achievable in the questionnaire ranges between 0-48. A high score indicates better sexual function ${ }^{(16)}$.

\section{Pelvic Floor Distress Inventory-20}

Pelvic floor distress symptoms, quality of life, and pelvic floor dysfunction severity were assessed using the reliable and condition-specific Turkish version of PFDI-20. PFDI20 consists of 3 subscales as Pelvic Organ Prolapse Distress Inventory-6 (POPDI-6), Urinary Distress Inventory-6 (UDI-6), and Colorectal-Anal Distress Inventory-8 (CRADI-8), and 20 questions. The subscale scores of PFDI-20 are 0-100 and the total scores (sum of three subscale scores) range from 0-300; high scores indicate more severe pelvic floor distress ${ }^{(17)}$.

\section{Statistical Analysis}

Sample size requirement was calculated using $G^{*}$ Power Manual 3.1.2.9(18) . According to the outputs, a total of 112 women were required to ensure $80 \%$ power with an alpha level 0.05 , and effect size was taken at the 0.4 level. The descriptive values of the obtained measurements were estimated as mean, median value, standard deviation, number and frequency. Whether the numerical characteristics showed normal distribution in each group was examined using the Shapiro-Wilk test. The Kruskal-Wallis test and post-hoc Dunn test were used for group comparisons. The statistical significance level was accepted as $\mathrm{p} \leq 0.05$ and the SPSS version 20-demo program was used in the estimations.

\section{Results}

Seven hundred twenty-one files were examined during this research. Three hundred sixty-one women among those were excluded for having urinary incontinence without POP, and 3 women were excluded for only having symptoms of fecal incontinence. When the remaining files were examined, it was determined that 357 women had POP. Among these, 5 women with mental problems, 64 women with the same stage POP in more than one compartment, 2 women who could not speak
Turkish, 59 who had not had a sexual relationship within the past 6 months, 12 with neurologic disorders, 23 women with a history pelvic surgery, and 24 women whose assessment forms were incomplete were not included in the study. A total of 168 women, comprising 96 women with anterior compartment prolapse, 20 women with apical compartment prolapse, 16 women with posterior compartment prolapse, and 36 women with asymptomatic POP were included in the final analysis (Figure 1).

The physical and sociodemographic characteristics of the women included in the research are shown in Tables 1 and 2. There was no difference found in terms of age and height of asymptomatic women, women with anterior, posterior, and

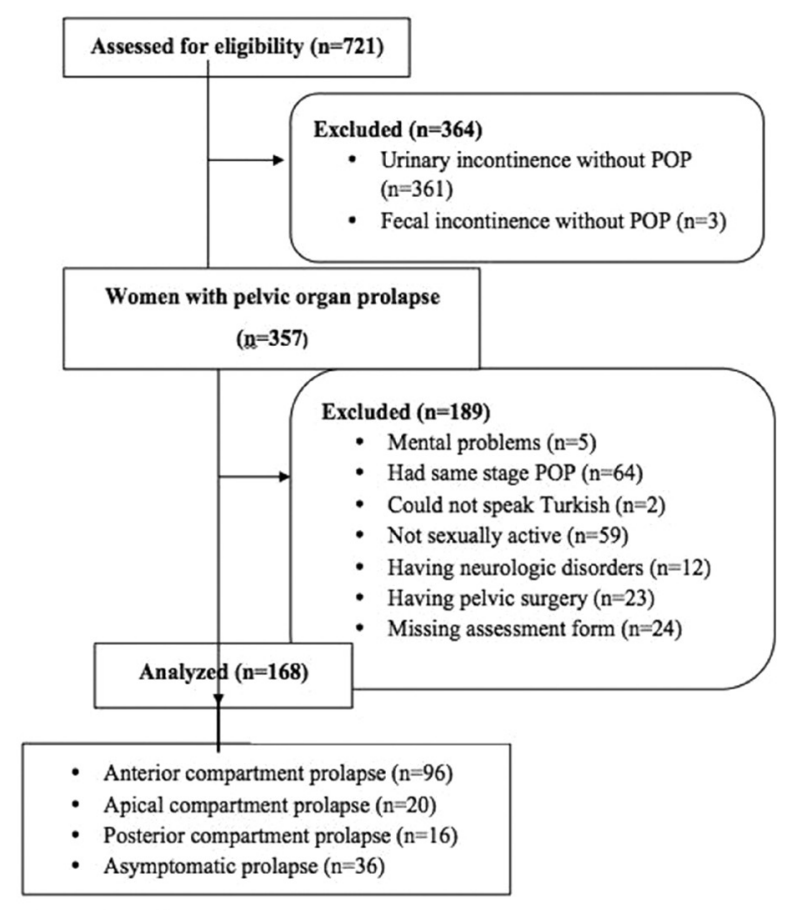

Figure 1. Enrollment diagram

POP: Pelvic organ prolapse

Table 1. Physical features of the women by prolapse type

\begin{tabular}{|c|c|c|c|c|c|c|c|}
\hline & $\begin{array}{l}\text { Anterior } \\
(\mathrm{n}=96)\end{array}$ & $\begin{array}{l}\text { Apical } \\
(n=20)\end{array}$ & $\begin{array}{l}\text { Posterior } \\
(n=16)\end{array}$ & $\begin{array}{l}\text { Asymptomatic } \\
(\mathrm{n}=36)\end{array}$ & $\mathrm{p}^{1}$ & $\begin{array}{l}\text { Group } \\
\text { comparison }\end{array}$ & $\mathrm{p}^{2}$ \\
\hline Age (years) & $49.38 \pm 10.242$ & $50.85 \pm 12.46$ & $52.81 \pm 13.85$ & $51.78 \pm 11.97$ & 0.43 & & \\
\hline Body height (m) & $1.57 \pm 0.06$ & $1.58 \pm 0.06$ & $1.56 \pm 0.05$ & $1.57 \pm 0.06$ & 0.87 & & \\
\hline Body weight (kg) & $75.58 \pm 12.82$ & $64.90 \pm 10.80$ & $74.37 \pm 12.42$ & $72.42 \pm 11.27$ & $0.00 *$ & Apical-anterior & $0.00 *$ \\
\hline BMI $\left(\mathrm{kg} / \mathrm{m}^{2}\right)$ & $30.42 \pm 5.30$ & $26.08 \pm 5.01$ & $30.30 \pm 5.37$ & $29.54 \pm 5.29$ & $0.01 *$ & Apical-anterior & $0.01 *$ \\
\hline
\end{tabular}

${ }^{1}$ Kruskal-Wallis test

${ }^{2}$ Post-hoc Dunn test

${ }^{*} \mathrm{p} \leq 0.05$

BMI: Body mass index 
Table 2. Sociodemographic characteristics of the women by prolapse type

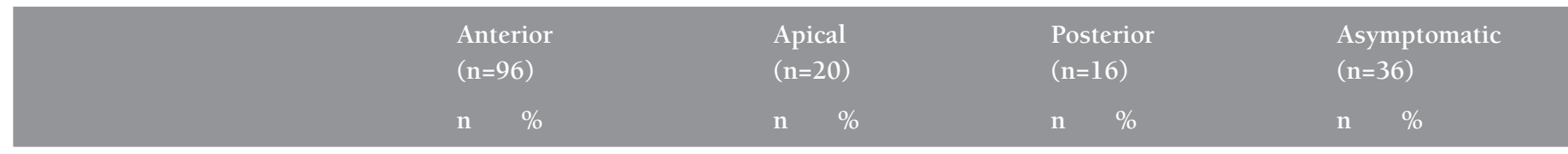

Educational status

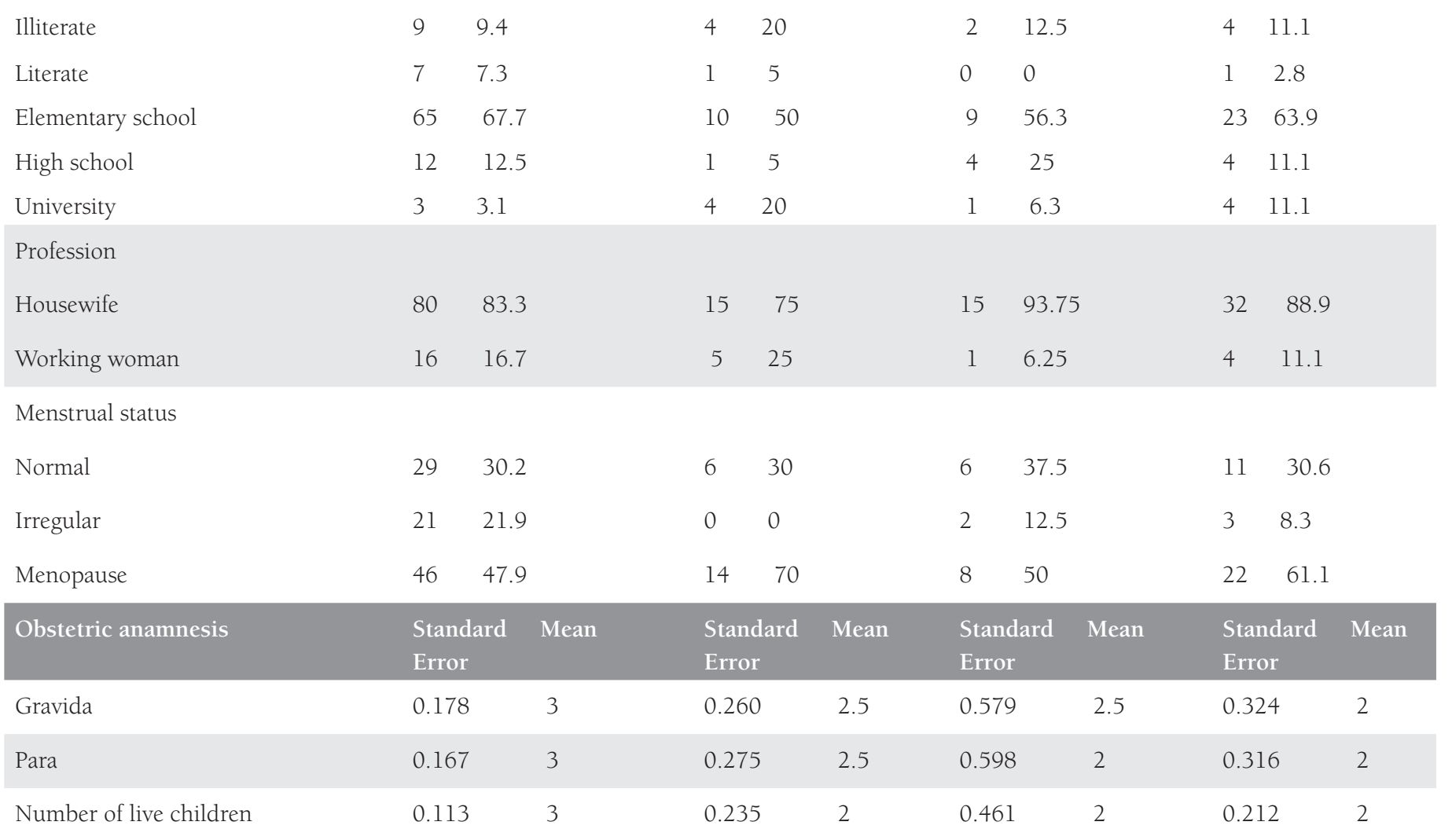

apical compartment prolapses ( $p>0.05)$. A statistical difference was determined in body weights $(p=0.003)$ and BMI $(p=0.011)$ of women with apical and anterior compartment prolapses. There was no difference found between the groups in terms of PISQ-12 total scores and behavioral/emotive, physical, partnerrelated subscales, PFDI-20 total scores, and CRADI-8, UDI-6 subscales, and muscle strength ( $p>0.05$, Table 3). POPDI-6 scores, a subscale of PFDI-20, exhibited statistically significant differences between asymptomatic women and women with anterior compartment prolapses $(p=0.044)$ and apical compartment prolapses $(\mathrm{p}=0.011)$.

\section{Discussion}

This retrospective study, conducted to scrutinize the effect of POP type on sexual function of women, showed that different prolapse types did not affect sexual function. Sexual function has a critical role in women's health, interest, and awareness in this field has been increasing gradually ${ }^{(19)}$. Sexuality depends on several factors including body image, socio-emotional perspective, sexual perception, quality of relationship with partner, and partner's desire and competency ${ }^{(20)}$. It is known that
POP mostly affects sexual function in the issues of sexual desire, orgasm ability, and arousal ${ }^{(10,21,22)}$. Psychological factors such as change in body image that could occur in women with POP, physiologic factors such as anatomic anomalies and diminished sensitivity in the genital region can lead to stimulation and orgasm disorders in women ${ }^{(12,23)}$.

Studies examining sexual function based on prolapse types are scarce. Mouritsen and Larsen ${ }^{(13)}$ showed that bladder, bowel, and sexual symptoms could be frequently seen in women with prolapses; however, they pointed out a very weak correlation between these symptoms and prolapse in a specific compartment. Lowenstein et al. ${ }^{(12)}$ reported that sexual function was not related with POP stage and vaginal compartment types but more related with body image perception and distress caused by POP level in women, rather than topographic changes based on POP. Lowenstein et al. ${ }^{(12)}$ concluded that women with poor body image had poor sexual functions. We found similar results in our research using the PISQ-12 to assess sexual function and by using the POP-Q system to determine prolapse type and stage. However, body image perceptions of these women were not able to be assessed due to the lack of a body image 
Table 3. Pelvic Organ Prolapse/Urinary Incontinence Sexual Questionnaire-12, Pelvic Floor Distress Inventory-20 and muscle strength assessment by prolapse type

\begin{tabular}{|c|c|c|c|c|c|c|c|}
\hline & $\begin{array}{l}\text { Anterior } \\
(n=96)\end{array}$ & $\begin{array}{l}\text { Apical } \\
(n=20)\end{array}$ & $\begin{array}{l}\text { Posterior } \\
(n=16)\end{array}$ & $\begin{array}{l}\text { Asymptomatic } \\
(\mathrm{n}=36)\end{array}$ & $\mathrm{p}^{1}$ & Group comparison & $\mathrm{p}^{2}$ \\
\hline PISQ-12 & $29.61 \pm 7.24$ & $29.60 \pm 6.38$ & $32.68 \pm 4.94$ & $30.00 \pm 7.05$ & 0.406 & & \\
\hline Behavioral/Emotive & $5.65 \pm 3.68$ & $4.40 \pm 4.28$ & $5.56 \pm 3.01$ & $5.05 \pm 3.85$ & 0.329 & & \\
\hline Physical & $12.37 \pm 3.92$ & $12.75 \pm 3.94$ & $14.68 \pm 1.77$ & $13.50 \pm 3.33$ & 0.097 & & \\
\hline Partner related & $11.58 \pm 2.71$ & $12.45 \pm 2.32$ & $12.43 \pm 2.06$ & $11.44 \pm 3.12$ & 0.542 & & \\
\hline \multirow[t]{2}{*}{ PFDI-20 } & $87.25 \pm 60.39$ & $79.78 \pm 54.08$ & $83.52 \pm 47.19$ & $67.73 \pm 53.29$ & 0.313 & & \\
\hline & $27.64 \pm 24.09$ & $33.53 \pm 28.56$ & $24.21 \pm 21.09$ & $16.08 \pm 20.04$ & $0.029 *$ & $\begin{array}{l}\text { Asymptomatic-anterior } \\
\text { Asymptomatic-apical }\end{array}$ & $\begin{array}{l}0.044^{*} \\
0.011 *\end{array}$ \\
\hline CRADI-8 & $18.81 \pm 19.12$ & $15.62 \pm 17.73$ & $30.66 \pm 20.67$ & $19.35 \pm 20.60$ & 0.119 & & \\
\hline UDI-6 & $40.79 \pm 29.25$ & $30.62 \pm 24.11$ & $28.64 \pm 18.99$ & $32.28 \pm 28.56$ & 0.204 & & \\
\hline Muscle strength $(\mathrm{hPa})$ & $21.83 \pm 13.55$ & $15.00 \pm 9.07$ & $23.43 \pm 15.70$ & $23.33 \pm 14.42$ & 0.158 & & \\
\hline $\begin{array}{l}{ }^{1} \text { Kruskal-Wallis test } \\
{ }^{2} \text { Post-hoc Dunn test } \\
{ }^{*} \mathrm{p} \leq 0.05 \\
\text { PISQ-12: Pelvic Organ Prolapse } \\
\text { Colorectal-Anal Distress Inven }\end{array}$ & 8 UDJ-6. Urinan & al Questionnaire- & $\begin{array}{l}\text { PFDI-20: Pelvic Flc } \\
\text { : Hectopascal }\end{array}$ & Distress Inventory-20 & PDI-6: Pelvi & Drgan Prolapse Distress Inventor & 6, CRADI-8 \\
\hline
\end{tabular}

questionnaire specific to prolapse in the literature during the period when data were collected.

The behavioral/emotive subscale of sexual function did not alter according to POP types in this study. Nevertheless, the scores received in the behavioral/emotive subscale were lower than those of the physical and partner-related subscales. The behavioral/emotive subscale examines sexual desire, sexual relationship frequency, and orgasm state of women. It was interesting that the scores in this subscale in the 4 groups were lower when compared with the other subscales. According to the literature search, the averages of the behavioral/emotive subscales in other studies that assessed sexual function using PISQ-12 or PISQ questionnaires were higher than the averages of the women in our study ${ }^{(22,24,25)}$. The considerably low averages of the behavioral/emotive subscales in different POP types and the lack of a difference between the groups gave rise to the thought that this situation may not be related to POP but may be related to the conservative perspective of Turkish society towards sexuality. It is thought that factors such as sexual appetite is regarded as wrong in Muslim societies and sexuality among women is regarded as a requirement for having children and making their husbands happy, which causes repressed sexuality ${ }^{(26)}$.

It was previously reported that pelvic floor muscle strength, endurance, vaginal resting pressure, and pelvic floor muscle thickness decreased in women with $\mathrm{POP}^{(27)}$. To our knowledge, no studies have examined the effect of POP type on muscle strength. In this study, it was seen that pelvic floor muscle strength was similar between the groups. It was found that the sum of the muscle strength scores of the women with posterior compartment prolapse were higher than those of the apical and anterior compartment, and they were almost the same in asymptomatic women. This situation stems from the support of the posterior compartment by the PB and levator ani muscles, in addition to facial support ${ }^{(28)}$.

The PFDI-20 is used frequently for the assessment of pelvic floor symptoms of women ${ }^{(2)}$. In our study, it was found that the total scores of pelvic floor distress, urinary, and colorectal-anal symptoms were similar. Prolapse symptoms in women with anterior and apical compartment POP were found more severe when compared with asymptomatic women. To the best of our knowledge, there are no studies in the literature investigating pelvic floor distress symptoms according to POP types. We think that the reason for the more severe prolapse distress symptoms among women with anterior and apical compartment prolapses, and the absence of a statistical difference between women with posterior compartment prolapse and asymptomatic women was the support of posterior structures with strong power such as the levator ani. In addition, the unequal and widely distributed numbers of patients included in this retrospective study may have affected the results. It is known that increased body weight is a risk factor for $\mathrm{POP}^{(29)}$. We anticipated that the BMIs of asymptomatic women would have been lower in this study, but there was no difference between the compartments. It was observed that the BMIs of women with apical compartment prolapses were lower than those of women with anterior compartment prolapses. 
The strength of this study was the inclusion of only women with $\mathrm{POP}$, the same race of women, and using a condition-specific questionnaire for sexual function. When it is considered that muscle strength could also affect sexual function, objective and the quantitative measurement of pelvic floor muscle strength of women was another strength of this research. Despite the conservative perspective of Turkey towards sexuality, questioning sexual function of women in a rural province was an extraordinary situation for a Muslim society.

\section{Study Limitations}

This research has a limitation due to its retrospective nature. It caused the exclusion of women who were sexually inactive because PISQ-12 is an appropriate questionnaire only for sexually active women. In 2013 the questionnaire was revised as the Pelvic Organ Prolapse/Incontinence Sexual Questionnaire, International Urogynecological Association-Revised (PISQIR), which also assesses sexually inactive women. However, the questionnaire could not be used because there was no Turkish version at the start date of the study. Another limitation of this study was the inclusion of only asymptomatic women with stage 1 prolapse as a control group and exclusion of women with stage 0 POP. Women with stage 0 POP were not accepted as the control group because they did not present to our women's health unit due to the lack of symptoms. Despite the presentation of women with stage 0 POP to our unit with pelvic floor dysfunction symptoms, this situation was the reason for our exclusion criterion. The lack of questioning sexual intercourse frequency, vaginal dryness, and body image perception are among our other limitations. It was reported in the literature that body image perception affected sexual function in particular, rather than POP's topographic changes ${ }^{(12)}$.

\section{Conclusion}

This study illustrated that sexual function and muscle strength may not be affected by prolapse type. It was determined that there were more prolapse symptoms and complaints in women with anterior and apical compartment prolapses. When it is considered that POP can exist in more than one compartment simultaneously, more studies are needed including women with more than one compartment prolapse with larger samples. We think that investigating the effect of $\mathrm{POP}$ on sexual desire with the inclusion of sexually inactive women will be influential to determine the negative aspects caused by POP with the addition of PISQ-IR to the literature. Although there is no difference when comparing sexual function relative to compartments, low behavioral/emotive sub-domain scores of women may actually indicate problems with their orgasm, frequency of sexual intercourse, and sexual desire. For this reason, clinicians should examine women without discriminating compartments and women should be directed to appropriate treatment.

\section{Ethics}

Ethics Committee Approval: The study was approved by the Abant İzzet Baysal University Local Ethics Committee (approval number: 2014/17).

Informed Consent: Consent form was filled out by all participants.

Peer-review: Externally peer-reviewed.

\section{Authorship Contributions}

Surgical and Medical Practices: N.Ö., Y.B., Concept: N.Ö., Y.B., Design: N.Ö., Y.B., Data Collection or Processing: N.Ö., Analysis or Interpretation: H.Ç., E.D., M.F.U., Literature Search: H.Ç., E.D., M.F.U., Writing: N.Ö., H.Ç., E.D., M.F.U., Y.B.

Conflict of Interest: No conflict of interest was declared by the authors.

Financial Disclosure: The authors declared that this study received no financial support.

\section{References}

1. ACOG Committee on Practice Bulletins--Gynecology. ACOG Practice Bulletin No. 85: Pelvic organ prolapse. Obstet Gynecol 2007;110:717-29

2. Hagen S, Stark D. Conservative prevention and management of pelvic organ prolapse in women. Cochrane Database Syst Rev 2011;CD003882.

3. Ellerkmann RM, Cundiff GW, Melick CF, Nihira MA, Leffler K, Bent AE. Correlation of symptoms with location and severity of pelvic organ prolapse. Am J Obstet Gynecol 2001;185:1332-8.

4. Digesu GA, Chaliha C, Salvatore S, Hutchings A, Khullar V. The relationship of vaginal prolapse severity tosymptoms and quality of life. BJOG 2005;112:971-6.

5. Chow D, Rodriguez LV. Epidemiology and prevalence of pelvic organ prolapse. Curr Opin Urol 2013;23:293-8.

6. Durnea C, Khashan A, Kenny L, Durnea U, Smyth M, O'Reilly B. Prevalence, etiology and risk factors of pelvic organ prolapse in premenopausal primiparous women. Int Urogynecol J 2014:25:1463-70.

7. Mothes A, Radosa M, Altendorf-Hofmann A, Runnebaum I. Risk index for pelvic organ prolapse based on established individual risk factors. Arch Gynecol Obstet 2015:1-8.

8. Jha S, Gopinath D. Prolapse or incontinence: what affects sexual function the most? Int Urogynecol J 2016;27:607-11.

9. Panman C, Wiegersma M, Kollen BJ, Berger MY, Lisman-Van Leeuwen Y, Vermeulen KM, Dekker JH. Two-year effects and cost-effectiveness of pelvic floor muscle training in mild pelvic organ prolapse: a randomised controlled trial in primary care. BJOG 2017;124:511-20.

10. Panman CM, Wiegersma M, Talsma MN, Kollen BJ, Berger MY, Lisman-Van Leeuwen Y, Dekker JH. Sexual function in older women with pelvic floor symptoms: a cross-sectional study in general practice. Br J Gen Pract 2014;64:e144-50.

11. Tok EC, Yasa O, Ertunc D, Savas A, Durukan H, Kanik A. The effect of pelvic organ prolapse on sexual function in a general cohort of women. J Sex Med 2010;7:3957-62.

12. Lowenstein L, Gamble T, Sanses TV, van Raalte H, Carberry C, Jakus $\mathrm{S}$, et al. Sexual function is related to body image perception in women with pelvic organ prolapse. J Sex Med 2009;6:2286-91.

13. Mouritsen L, Larsen JP. Symptoms, bother and POPQ in women referred with pelvic organ prolapse. Int Urogynecol J Pelvic Floor Dysfunct 2003;14:122-7. 
14. Bump RC, Mattiasson A, Bø K, Brubaker LP, DeLancey JO, Klarskov $\mathrm{P}$, et al. The standardization of terminology of female pelvic organ prolapse and pelvic floor dysfunction. Am J Obstet Gynecol 1996;175:10-7.

15. Bø K, Sherburn M. Evaluation of female pelvic-floor muscle function and strength. Phys Ther 2005;85:269-82.

16. Bilgic Celik D, Beji NK, Yalcin O. Turkish adaptation of the short form of the Pelvic Organ Prolapse/Urinary Incontinence Sexual Function Questionnaire (PISQ-12): a validation and reliability study. Neurourol Urodyn 2013;32:1068-73.

17. Celenay ST, Akbayrak T, Kaya S, Ekici G, Beksac S. Validity and reliability of the Turkish version of the Pelvic Floor Distress Inventory-20. Int Urogynecol J 2012;23:1123-7.

18. Faul F, Erdfelder E, Lang A-G, Buchner A. G* Power 3: A flexible statistical power analysis program for the social, behavioral, and biomedical sciences. Behav Res Methods 2007;39:175-91.

19. Lowenstein L, Pierce K, Pauls R. Urogynecology and sexual function research. How are we doing? J Sex Med 2009;6:199-204.

20. Brækken IH, Majida M, Ellström Engh M, Bo K. Can pelvic floor muscle training improve sexual function in women with pelvic organ prolapse? A randomized controlled trial. J Sex Med 2015;12:470-80.

21. Athanasiou S, Grigoriadis T, Chalabalaki A, Protopapas A, Antsaklis A. Pelvic organ prolapse contributes to sexual dysfunction: a crosssectional study. Acta Obstet Gynecol Scand 2012;91:704-9.
22. Novi JM, Jeronis S, Morgan MA, Arya LA. Sexual function in women with pelvic organ prolapse compared to women without pelvic organ prolapse. J Urol 2005;173:1669-72.

23. Gruenwald I, Mustafa S, Gartman I, Lowenstein L. Genital sensation in women with pelvic organ prolapse. Int Urogynecol J 2015;26:981-4.

24. Rogers G, Villarreal A, Kammerer-Doak D, Qualls C. Sexual function in women with and without urinary incontinence and/or pelvic organ prolapse. Int Urogynecol J Pelvic Floor Dysfunct 2001;12:361-5.

25. Tsai KK, Marques F, Myers DL, Sung VW. Association between obesity, sexual activity and sexual function in women with pelvic floor disorders. Female Pelvic Med Reconstr Surg 2010;16:331-5.

26. İncesu C. Cinsel işlevler ve cinsel işlev bozuklukları. Klinik Psikiyatri 2004;7:3-13.

27. Braekken IH, Majida M, Engh ME, Bo K. Are pelvic floor muscle thickness and size of levator hiatus associated with pelvic floor muscle strength, endurance and vaginal resting pressure in women with pelvic organ prolapse stages I-III? A cross sectional 3D ultrasound study. Neurourol Urodyn 2014;33:115-20.

28. Ali-Ross N, Smith A, Hosker G. The effect of physical activity on pelvic organ prolapse. BJOG 2009;116:824-8.

29. Jelovsek JE, Maher C, Barber MD. Pelvic organ prolapse. Lancet 2007;369:1027-38. 